\title{
On the Current Situation and Countermeasures of Chinese Teaching in Higher Vocational Colleges
}

\author{
Tang Jianghua \\ Yunnan College Foreign Languages and Foreign Affairs Yanglin 651700 \\ 85463999@qq.com
}

Keywords: Higher Vocational Chinese; current situation; countermeasures

\begin{abstract}
As China's higher vocational education is positioned to cultivate skilled talents, it is often misunderstood in teaching arrangements. It only pays attention to instilling technology and despise humanistic quality, resulting in a misunderstanding of higher vocational Chinese teaching. This article discusses the problems and countermeasures of the Chinese teaching in higher vocational education, hoping to arouse the attention of higher vocational colleges.

Higher vocational Chinese is an important course to improve students' cultural quality and cultivate humanistic sentiments. It is an important carrier for the transmission of humanistic ideas in higher vocational education. Therefore, higher vocational Chinese plays a decisive role in higher vocational education. However, as one of the basic courses in higher vocational colleges, the teaching status of Chinese courses is not very optimistic. Language teaching has always been dispensable and insignificant. Although the Ministry of Education held a seminar on university language teaching reform in institutions of higher learning, the Ministry of Education proposed that all higher vocational colleges should set up language classes, but the institutions are not actually implemented and implemented, even if many institutions are opened only Perfunctory response. Combining the higher vocational colleges and universities to cultivate more skilled talents, the emphasis on practice in training orientation has resulted in the poor expression of students' language skills and low humanistic quality. Therefore, we must redefine the position of Chinese education in higher vocational education.
\end{abstract}

\section{First of all, The Current situation of Chinese Education in Higher Vocational Education}

\section{Inaccurate positioning of Chinese teaching}

Higher vocational colleges are in line with the goal of "cultivating students' professional and technical skills" and neglect the cultivation of students' humanistic qualities. In particular, some higher vocational colleges have simply cancelled the Chinese language curriculum, and have changed their specialty courses to supplement professional ones. Problems, even if some of the majors are offered, are taken as elective courses, causing serious shortage of language lessons. Because it failed to attract enough attention, it caused many college graduates to use language skills and could not express clearly. Even a letter of recommendation for graduation would not be written. Higher vocational colleges have even forgotten that the purpose of education should be the cultivation of students' overall quality. This is a major feature of higher vocational college teaching.

\section{Insufficient quality of teachers}

The so-called "master leads in and practices in the individual" is influenced by the ideology and culture of Confucianism. Many teachers think that the teacher is a teacher who "preaches, teaches, and confuses," and the teaching methods of the teacher are outdated. A teaching book, a notebook, a blackboard and a chalk are filled in the end. Coupled with the low comprehensive quality of many language teachers in higher vocational colleges, whether in terms of age, academic qualifications, or title structure, it is impossible to improve the quality of Chinese teaching, so that students do not have the interest in language learning.

\section{Antiqued books}

In the selection of teaching materials, colleges often focus on ideological, classical, and educational characteristics, which is inconsistent with students' ability to accept. In the compilation 
of teaching materials, we still follow the senior four teaching arrangements, and we are too rigid to use standardized systems and genres to improve students' enthusiasm for learning. However, this method of arrangement is not conducive to the improvement of teachers' teaching methods. Facilitate students' learning and interest.

\section{Single method of teaching evaluation}

In most vocational colleges, Chinese education is only a form of a test paper to assess students. The evaluation of teachers is the end of term evaluation, which is simple and clear. Therefore, higher vocational students are only the most primitive educational models for language learning. Wrote memorization, mechanized learning. This kind of evaluation method does not allow higher vocational students to express their own needs, resulting in their loss of enthusiasm for higher vocational language education. Serious students may be able to give up on language learning.

\section{Student motivation is not high}

Higher vocational colleges are generally faced with the problem of poor pupils' students. These students have a poor general cultural foundation and bad study habits. After entering higher vocational colleges, their own ideas are more lax and have little interest in language learning in higher vocational schools. Graduation positions and skills requirements, students' employment pressure, these students hold a mixed diploma attitude to learning, lack of social experience, the purpose is not strong, and the initiative to learn is weak.

\section{What's more, The Reform Strategy of Chinese Teaching in Higher Vocational Education.}

\section{Update education concept, precise positioning}

In order to change the embarrassing situation in higher vocational Chinese teaching, we must first improve the understanding of teaching management in higher vocational colleges, increase the emphasis on higher vocational Chinese teaching, and improve the status of Chinese teaching. Second, language is an important foundation for other professional disciplines. Therefore, Chinese language teaching lies in improving students' understanding ability, analytical ability, and ability to solve problems. This makes it easier to grasp professional skills. Therefore, Chinese language teaching must be combined with professional skills courses. For example, nursing majors in our hospital must set up Chinese language courses for students to better communicate with patients and master language skills. At the same time, they also strengthen the recognition of words and characters, and they also demonstrate the humanistic qualities of doctors in order to prescribe prescriptions at work. Only the teaching staff and students fully understand the importance of good language education, so as to promote teacher's teaching and student's learning.

\section{Strengthen the Training of Teachers' Quality}

In higher vocational education, teachers as the main body of teaching in higher vocational Chinese education are of vital importance to the entire teaching class. Language teachers cannot simply be regarded as language communicators, and teachers' literacy should be improved as a whole. At the same time, outstanding teachers are the guarantee for schoolteachers and curriculum team building. Schools should try to retain outstanding teachers, establish a reasonable rewards and punishments system, increase the training of masters, encourage teachers to reform teaching methods, and cultivate professional leaders, backbone teachers, the establishment of a noble teacher, exquisite business, combined with structural optimization, dynamic teaching team.

\section{Reasonable teaching material selection}

Teaching materials are the basis for teacher teaching and student learning. There is no good teaching material and only appropriate teaching materials. The teaching content of higher vocational Chinese language should be integrated with the times, highlight the characteristics of the times, focus on real life teaching experience, strengthen the connection between the classroom and reality, expand the teaching resources as much as possible, and integrate the textbooks with modern teaching methods. For example: Micro lessons, admiring lessons, flipping classes, etc. Even if the materials are fully utilized, they can stimulate students' interest in learning.

\section{Teaching evaluation system establishment}

The evaluation of higher vocational Chinese education is a summary of the expected 
accomplishment in the teaching process of higher vocational Chinese education, the realization of examination goals, and the degree of educational efficiency. It is an indispensable part of the innovation of Chinese teaching in higher vocational education. Take our school as an example. Our appraisal of teachers is only the final evaluation of education, and more consideration is given to the teacher's usual teaching effectiveness evaluation, teaching standards, scientific research participation, and student feedback in class. And for the exam is not a final exam paper, the school now uses a computer test, a comprehensive reply and so on. The evaluation method has undergone great changes. Students no longer learn Chinese for the sake of the exam, they are no longer afraid of the language exams, and they are full of information each time they are tested. At the same time, teachers also reduce some of the end-of-term review workload.

\section{Improve student motivation}

The reason why vocational education has not been substantially improved is because the enthusiasm and initiative of students have not been improved. At the same time, due to the students' characteristics of students in higher vocational colleges, it is necessary for our teachers to change their methods in the teaching process. The teaching concept, truly the theory and practice of vocational education, enhances the professional knowledge and professional ability of students while the quality of humanities has also been well developed and the overall quality of students has been improved.

Language in higher vocational education is an indispensable key course to enhance the overall quality of students. For higher vocational education, the new situation and the complex talents with high comprehensive quality and core competence that society needs, we only pay attention to the cultivation of students' professional skills, and we must also pay attention to the cultivation of humanistic qualities. At the same time, in the process of Chinese teaching in higher vocational colleges, it explores the characteristics suitable for the cultivation of the talents in the university, and carries out teaching reforms in the Chinese language according to its actual situation.

\section{References}

[1] Li Yueqiong, Wang Jingling, Analysis and Reform Strategy of Chinese Teaching in Higher Vocational Colleges [J], Teaching Reform

[2]Ma Caiyun, Predicament of Chinese Language Education in Higher Vocational Colleges and Attempt of Creative Education, Industry and Technology Forum [J], Volume 12, Number 7 2013

[3] Wang Lei, On Problems and Suggestions of Chinese Teaching in Higher Vocational Colleges, Reading and writing magazines [J], June 2017 Volume 14 Number 06

[4] Feng Jie, Reflections on Employment-Oriented Reform of Chinese Teaching in Vocational Colleges, Education modernization [J], 2018.05

[5] Long Yufan, Highlighting the Practical Ability of Chinese Teaching in Vocational Colleges, Education modernization [J], 2017.4 (27)

1 Tang jiang hua(1981.11 --) Master's degree, lecturer, backbone teacher, Yunnan Foreign Language Vocational College, Tel: $1388824476785463999 @ q q . c o m$ 